\title{
The Top 100 Most Cited Articles on Intrauterine Adhesion: a Bibliometric Analysis
}

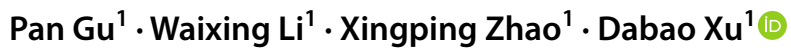

Received: 13 August 2021 / Accepted: 1 November 2021 / Published online: 15 November 2021

(c) The Author(s) 2021

\begin{abstract}
Bibliometric analysis is a statistical method that attempts to assess articles by their citations, analyzing their frequency and citation pattern, which subsequently gleans direction and guidance for future research. Over the past few years, articles focused on intrauterine adhesions have been published with increasing frequency. Nevertheless, little is known about the properties and qualities of this research, and no current analysis exists that has examined the progress in intrauterine adhesion research. Web of Science Core Collection, BIOSIS Citation Index, and MEDLINE database were searched to identify articles on intrauterine adhesion published from 1950 to October 2020. The 100 most cited articles were chosen to analyze citation count, citation density, authorship, theme, geographic distribution, time-related flux, level of evidence, and network analysis. An overwhelming majority of these 100 articles were published in the 2010 s (35\%). Citations per article ranged from 30 to 253 . Chinese authors published the most papers in the top 100, followed by the USA, France, Israel, and Italy. The most salient study themes included operative hysteroscopy and adjunctive treatments for improving reproductive outcomes. The most common level of evidence was level II, and there was no statistical difference in the number of citations between the levels. The network analysis indicated that hysteroscopy, hysteroscopic adhesiolysis, infertility, and the reproductive outcome had a great degree of centrality in the 2000s and 2010s. In comparison, placental implantation had a great degree of centrality in the 2000s, and stem cell and fibrosis had a great degree of centrality in the 2010s. The value of IUA investigation has been gradually appreciated recently. Hysteroscopic adhesiolysis was continuously explored to achieve better reproductive outcome. Over time, the main focus of research has gradually shifted from complications to postoperative adjuvant treatment. Moreover, breakthrough progress is needed in underlying mechanism and early prevention of IUA.
\end{abstract}

Keywords Intrauterine adhesion $\cdot$ Hysteroscopy $\cdot$ Hysteroscopic adhesiolysis $\cdot$ Bibliometric analysis

\section{Introduction}

Pan Gu and Waixing Li contributed equally to this work

\section{Key Message}

As articles focused on intrauterine adhesion (IUA) have recently been published with increasing frequency, our study aimed to evaluate the properties and qualities of these studies through bibliometric analysis.

\footnotetext{
Xingping Zhao

zxp8846@126.com

dabaoxu@yahoo.com

1 Department of Gynecology, Third Xiangya Hospital, Central South University, 138 Tongzipo Road, Changsha 410013, Hunan, China
}

$\triangle$ Dabao Xu
Intrauterine adhesion (IUA) was first defined and reported by Asherman in 1950 [1, 2]. IUA is caused by mechanical injury or damage from infection to the basal layer of the endometrium, resulting in the formation of fibromuscular or severe connective tissue adhesion of the uterine cavity or cervical canal [3, 4]. Hypomenorrhea/amenorrhea [5], infertility[6], recurrent pregnancy loss [7], and obstetric complications [8] are common complications of IUA, and IUA may also lead to low birth weight [9]. At present, IUA remains a relatively intractable disease that seriously affects women's reproductive prognosis and quality of life in childbearing age $[6,10]$.

Surgical treatment is the first choice for IUA. However, hysteroscopic adhesiolysis, the standard treatment for IUA, confers limited therapeutic benefit [11]. After hysteroscopic 
adhesiolysis, the conception rate is $25 \%$, and the rate of reformation of adhesions is $20-63 \%$ [12-15]. In order to reduce the recurrence rate of IUA and improve reproductive prognosis, the application of other preventative and treatment measures for comprehensive management of adhesions after the surgery is recommended [16-18]. These measures mainly include devices to keep opposing endometrial surfaces separated, such as intrauterine device (IUD) [19]; Foley catheter balloon [20]; auto-crosslinked hyaluronic acid (ACP) gel [21-24]; and interventions to promote endometrial regeneration, such estrogen [25, 26], stem cell [27-29], stem cell exosome [30], amniotic epithelial cells [31], granulocyte colony-stimulating factor [32], platelet-rich plasma [33], and aspirin [34]. However, the efficacy of these measures is still not ideal: the reformation rate is as high as $48 \%$ [35], the conception rate is about $44.3 \%$, and the live birth rate is $37.8 \%$ [36]. Therefore, reducing the reformation rate of IUA and increasing the postoperative conception rate and live birth rate have remained the focus of IUA research.

The current study aimed to identify the 100 most cited essays in the field of IUA, ascertain the research trends and hotspots in this area, and evaluate the research quality and properties of the most cited original papers over the past 70 years. We intend that the findings from this analysis can guide subsequent research in IUA.

\section{Methods}

\section{Search Strategy}

All articles were selected through a search of the Web of Science Core Collection, BIOSIS Citation Index, and MEDLINE to retrieve all articles related to IUA. Two individuals simultaneously conducted the search process to enhance the search sensitivity. The terms used for searching were as follows: Intrauterine adhesion OR Asherman Syndrome.

The search was conducted in October 2020 and yielded a total of 1999 results. Subsequently, search results were filtered. Only original articles were included, meaning reviews, systematic reviews, meta-analyses, and guidelines were all excluded. To limit the number of screened articles, those articles that were cited fewer than 10 times were excluded. As a result, 418 articles were included for analysis. Two independent researchers reviewed the title and the abstract of the selected articles. Articles that met any of the following criteria were included: (1) basic study, animal study, and clinical trials related to any aspect of IUA; (2) the clinical therapeutic, prognostic, diagnostic, epidemiological studies of IUA; or (3) the case report data of IUA. Any disagreements between the 2 reviewers were discussed until a consensus was reached. After the title and abstract review were completed, 241 articles remained. These articles were ranked in descending order of citations, and the top 100 most cited articles were included in this analysis (Fig. 1).

\section{Data Extraction}

Two independent, well-trained individuals reviewed all articles. The following information was listed for all articles: the journal name, publication date, first author, year of publication, geographic origin, the total number of citations of the article, overall citation rate (total citations/article age), research theme, and level of evidence (methodology has been described elsewhere [37]).

\section{Statistical Analysis}

The Shapiro-Wilk test was used to test the distribution of individual variables for normality. Normally distributed data are presented as mean \pm standard deviation. Comparison between means was performed using one-way analysis of variance (ANOVA), and post hoc testing was conducted as necessary. Time-dependent trends were tested using the Mann-Kendall trend test. Correlation between variables was performed using the Spearman rank or Pearson tests. A $P$ value $<0.05$ was considered to be statistically significant. Analysis was performed using SPSS Statistics 20.0 (IBM

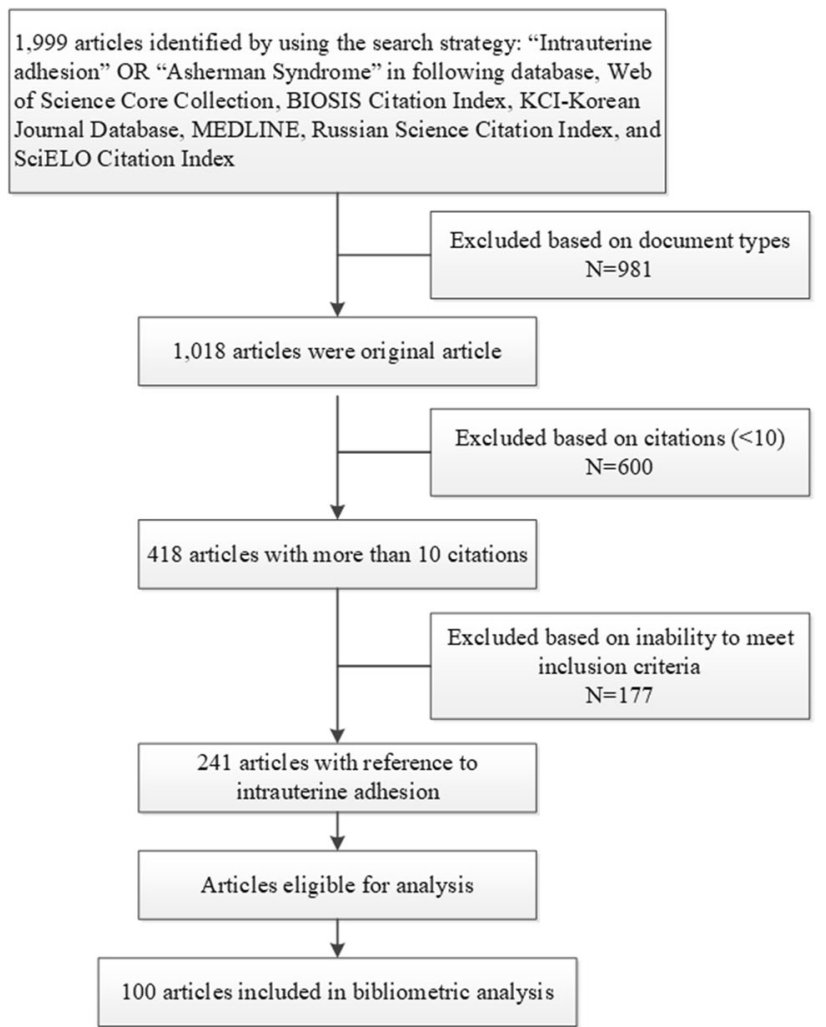

Figure 1 Flowchart illustrating the process of allocation of articles 
Corp., Armonk, NY, USA). UCINET for Windows, version 6.212 , was used to perform the degree of centrality analysis [38].

\section{Results}

We extracted the top 100 most cited articles in the field of IUA (listed in Table 1). Citations ranged from 30 to 253 in number, with a majority being published in the $2000 \mathrm{~s}$ (29\%) and 2010s (35\%), indicating an overall trend of yearby-year increase publication (Fig. 2). The year 2008 saw the highest number of these IUA articles published $(n=7)$. The number of citations was 6462 overall: $47(0.7 \%)$ in the $1960 \mathrm{~s}, 356(5.5 \%)$ in the $1970 \mathrm{~s}, 721(11.2 \%)$ in the $1980 \mathrm{~s}$, $1190(18.4 \%)$ in the 1990s, 2097 (32.5\%) in the 2000s, and $2051(31.7 \%)$ in the 2010s. The Mann-Kendall trend test showed no time-dependent trend in the publication time of articles $(P=0.4654)$ but did reveal an increasing trend between the citation density and time ( $P=2.2 \mathrm{E}-16$; Fig. 3$)$. The Spearman rank analysis indicated a positive correlation between time and citation density $(r=0.836 ; P<2.2 \mathrm{E}-16)$. The Shapiro-Wilk test and the Kolmogorov-Smirnov test both indicated an abnormal distribution of the citation data. The Shapiro-Wilk test indicated significant departures from normality $(P<0.05)$ for all distributions tested.

These articles were distributed in 22 countries (Fig. 4), led by China $(n=19)$ and followed by the USA $(n=18)$, France $(n=8)$, Israel $(n=8)$, and Italy $(n=8)$. The allocation is presented on the world map (Fig. 5). In terms of regional distribution, most of the articles were published in two continents: North America and Asia. The other articles were scattered in Europe, Africa, and Oceania. Developed countries accounted for $67 \%$ of all countries mentioned above. In all, 33 journals accounted for all the articles published, among which 27 were published in Fertility and Sterility, 16 in Human Reproduction, 6 in American Journal of Obstetrics and Gynecology, and 5 in Journal of Minimally Invasive Gynecology (Table 2).

Among the authors of the 100 most cited articles, 10 had more than 2 articles (Table 3). These authors' articles are all clinical studies related to IUA. Among them, March and Yang had 3 first authorships, mainly in the field of IUA. March's focus was on hysteroscopic adhesiolysis, and Yang's research direction was endometrial regeneration. Although Valle had only 2 articles, which were mainly focused on the auxiliary diagnosis of IUA, the number of citations was relatively high, with an overall number of citations of 286 .

The 100 most cited articles centered primarily on the following themes: auxiliary treatment of IUA $(n=28)$, the prognosis of IUA $(n=19)$, incentive factors of IUA $(n=16)$, hysteroscopic adhesiolysis ( $n=14)$, evaluation methods for IUA $(n=12)$, complications of IUA $(n=6)$, relevant mechanism of IUA $(n=4)$, and new devices for IUA $(n=1)$. The most frequently mentioned theme was the adjuvant treatment of IUA, followed by the reproductive prognosis of patients after hysteroscopic adhesiolysis (Fig. 6). One-way ANOVA revealed no significant difference in the citations per article across the various themes (Fig. 7). Nevertheless, the article's impact factor from different themes was statistically different $(P=0.012)$ (Fig. 8).

In terms of the level of article evidence, the level II $(n=39)$ category had a mean of $69 \pm 48$ citations per article, representing the largest number among the levels; the level I $(n=23)$ category had a mean $63 \pm 30$ citations per article, while level IV $(n=14)$ had $48 \pm 22$ citations. One-way ANOVA indicated that the differences in citations per article between different levels of evidence were not significant (Fig. 9).

Network analysis of the keywords or subject terms was conducted in 2 periods of publication: in the 2000s (34 articles) and the 2010s (30 articles). The result indicated that "hysteroscopy", "hysteroscopic adhesiolysis", "infertility", and "reproductive outcome" possessed a high degree of centrality in the 2000s and 2010s; "placenta accreta" was considerably centralized in the 2000s; and "stem cell" and "fibrosis" were highly concentrated in the 2010s (Figs. 10, $11)$.

\section{Discussion}

This is the first bibliometric analysis of papers in the field of IUA. Several interesting findings can be drawn from this analysis of the top 100 most cited papers published on IUA over the past 70 years, which include insights into those papers which had made important contributions to the progress in the field and the current trends in development. Generally, it is expected that as time passes, the number of citations of papers would increase. However, contrary to this expectation, when we assessed the 100 most cited articles by decade, we found that articles published in the $2010 \mathrm{~s}$ accounted for the highest proportion, reaching 35\%; as time elapsed, both the numbers of articles and the citation density (i.e., number of citations divided by the number of years) grew. For one, this reflects the "obliteration by incorporation" [39] in the field, in which the citations of the original work decrease with time due to its familiarity and long-term, widespread use, coupled with the effect of replacement by novel findings. For another, this indicates that the diagnosis, treatment, and advanced research related to IUA have attracted more of the international community's attention. In addition, $91 \%$ of these articles were clinical studies, and only $9 \%$ were basic experimental studies, with these basic studies all being published in the 2010s. Although clinical research has always been the focus of researchers in the field 
Table 1 List of the top 100 most-cited articles in intrauterine adhesion research

\begin{tabular}{|c|c|c|c|c|}
\hline Rank & Publication year & Total citation & Title & PMCID \\
\hline 1 & 1996 & 253 & Frequency of factors associated with habitual abortion in 197 couples & 8752606 \\
\hline 2 & 2000 & 236 & $\begin{array}{l}\text { Diagnostic accuracy at sonohysterography, transvaginal sonography, and hysterosalpingog- } \\
\text { raphy in patients with uterine cavity diseases }\end{array}$ & 10685551 \\
\hline 3 & 1988 & 204 & $\begin{array}{l}\text { Intrauterine adhesions: hysteroscopic diagnosis, classification, treatment, and reproductive } \\
\text { outcome }\end{array}$ & 3381869 \\
\hline 4 & 2004 & 137 & $\begin{array}{l}\text { Effectiveness of auto-crosslinked hyaluronic acid gel in the prevention of intrauterine adhe- } \\
\text { sions after hysteroscopic surgery: a prospective, randomized, controlled study }\end{array}$ & 15105384 \\
\hline 5 & 1978 & 133 & Hysteroscopic management of intrauterine adhesions & 637078 \\
\hline 6 & 2003 & 129 & $\begin{array}{l}\text { Effectiveness of auto-cross-linked hyaluronic acid gel in the prevention of intrauterine adhe- } \\
\text { sions after hysteroscopic adhesiolysis: a prospective, randomized, controlled study }\end{array}$ & 12923149 \\
\hline 7 & 2016 & 119 & $\begin{array}{l}\text { Autologous cell therapy with CD133+bone marrow-derived stem cells for refractory Asher- } \\
\text { man syndrome and endometrial atrophy: a pilot cohort study }\end{array}$ & 27005892 \\
\hline 8 & 2011 & 117 & $\begin{array}{l}\text { Endometrial regeneration using autologous adult stem cells followed by conception by } \\
\text { in vitro fertilization in a patient with severe Asherman's syndrome }\end{array}$ & 21772740 \\
\hline 9 & 2003 & 114 & A comparison of two adjunctive treatments for intrauterine adhesions following lysis & 12834941 \\
\hline 10 & 2014 & 114 & $\begin{array}{l}\text { Bone Marrow-Derived Stem Cell (BMDSC) transplantation improves fertility in a Murine } \\
\text { Model of Asherman's Syndrome }\end{array}$ & 24819371 \\
\hline 11 & 2008 & 108 & $\begin{array}{l}\text { Factors affecting the reproductive outcome of hysteroscopic adhesiolysis for Asherman's } \\
\text { syndrome }\end{array}$ & 17681324 \\
\hline 12 & 1999 & 102 & Hysteroscopic treatment of severe Asherman's syndrome and subsequent fertility & 10325268 \\
\hline 13 & 2004 & 99 & 1000 office-based hysteroscopies before in vitro fertilization: feasibility and findings & 15119651 \\
\hline 14 & 2010 & 97 & $\begin{array}{l}\text { Reproductive outcome following hysteroscopic adhesiolysis in patients with infertility due } \\
\text { to Asherman's syndrome }\end{array}$ & 19455349 \\
\hline 15 & 1998 & 94 & $\begin{array}{l}\text { Prevalence of Asherman's syndrome after secondary removal of placental remnants or a } \\
\text { repeat curettage for incomplete abortion }\end{array}$ & 9886512 \\
\hline 16 & 2012 & 93 & Comprehensive management of severe Asherman syndrome and amenorrhea & 22100167 \\
\hline 17 & 1978 & 91 & Diagnostic and therapeutic hysteroscopy for traumatic intrauterine adhesions & 677196 \\
\hline 18 & 1993 & 90 & $\begin{array}{l}\text { Incidence of post-abortion intra-uterine adhesions evaluated by hysteroscopy--a prospective } \\
\text { study }\end{array}$ & 8473464 \\
\hline 19 & 1997 & 89 & $\begin{array}{l}\text { Hysteroscopic treatment of intrauterine adhesions is safe and effective in the restoration of } \\
\text { normal menstruation and fertility }\end{array}$ & 9418714 \\
\hline 20 & 2008 & 87 & Postoperative adhesiolysis therapy for intrauterine adhesions (Asherman's syndrome) & 18571166 \\
\hline 21 & 2010 & 84 & $\begin{array}{l}\text { Prevalence of unsuspected uterine cavity abnormalities diagnosed by office hysteroscopy } \\
\text { before in vitro fertilization }\end{array}$ & 20570971 \\
\hline 22 & 1980 & 82 & Hysteroscopy in the evaluation of female infertility & 7386525 \\
\hline 23 & 2006 & 82 & Amnion graft following hysteroscopic lysis of intrauterine adhesions & 17100817 \\
\hline 24 & 2006 & 78 & Fertility after treatment of Asherman's syndrome stage 3 and 4 & 16962521 \\
\hline 25 & 2013 & 77 & $\begin{array}{l}\text { A comparison of the intrauterine balloon, intrauterine contraceptive device and hyaluronic } \\
\text { acid gel in the prevention of adhesion reformation following hysteroscopic surgery for } \\
\text { Asherman syndrome: a cohort study }\end{array}$ & 23932377 \\
\hline 26 & 2010 & 75 & $\begin{array}{l}\text { Human amnion as a temporary biologic barrier after hysteroscopic lysis of severe intrauter- } \\
\text { ine adhesions: a pilot study }\end{array}$ & 20576472 \\
\hline 27 & 1995 & 73 & $\begin{array}{l}\text { Reproductive outcome following hysteroscopic management of intrauterine septum and } \\
\text { adhesions }\end{array}$ & 8567788 \\
\hline 28 & 2004 & 72 & $\begin{array}{l}\text { Live delivery rates in subfertile women with Asherman's syndrome after hysteroscopic } \\
\text { adhesiolysis using the resectoscope or the Versapoint system }\end{array}$ & 15169591 \\
\hline 29 & 2011 & 72 & $\begin{array}{l}\text { Hysteroscopic management of residual trophoblastic tissue is superior to ultrasound-guided } \\
\text { curettage }\end{array}$ & 22024264 \\
\hline 30 & 2000 & 71 & $\begin{array}{l}\text { Predictive value of transvaginal sonography performed before routine diagnostic hysteros- } \\
\text { copy for evaluation of infertility }\end{array}$ & 10685552 \\
\hline 31 & 2006 & 69 & $\begin{array}{l}\text { Reduction of postoperative adhesions with an auto-crosslinked hyaluronan gel in gyneco- } \\
\text { logical laparoscopic surgery: a blinded, controlled, randomized, multicentre study }\end{array}$ & 16439505 \\
\hline 32 & 1986 & 68 & Severe obstetric complications after aggressive treatment of Asherman syndrome & 3703411 \\
\hline
\end{tabular}


Table 1 (continued)

\begin{tabular}{|c|c|c|c|c|}
\hline Rank & Publication year & Total citation & Title & PMCID \\
\hline 33 & 2013 & 68 & $\begin{array}{l}\text { Optimal waiting period for subsequent fertility treatment after various hysteroscopic surger- } \\
\text { ies }\end{array}$ & 23433831 \\
\hline 34 & 2014 & 66 & $\begin{array}{l}\text { Etiology, treatment, and reproductive prognosis of women with moderate-to-severe intrau- } \\
\text { terine adhesions }\end{array}$ & 24598346 \\
\hline 35 & 2015 & 66 & $\begin{array}{l}\text { Human CD133(+) bone marrow-derived stem cells promote endometrial proliferation in a } \\
\text { murine model of Asherman syndrome }\end{array}$ & 26384164 \\
\hline 36 & 2009 & 65 & $\begin{array}{l}\text { Uterine synechiae after bipolar hysteroscopic resection of submucosal myomas in patients } \\
\text { with infertility }\end{array}$ & 18937941 \\
\hline 37 & 2008 & 64 & $\begin{array}{l}\text { Efficiency and pregnancy outcome of serial intrauterine device-guided hysteroscopic adhesi- } \\
\text { olysis of intrauterine synechiae }\end{array}$ & 18774563 \\
\hline 38 & 2010 & 64 & Fertility and pregnancy following pelvic arterial embolization for postpartum hemorrhage & 19832826 \\
\hline 39 & 2003 & 63 & $\begin{array}{l}\text { A prospective comparative study between hysterosalpingography and hysteroscopy in the } \\
\text { detection of intrauterine pathology in patients with infertility }\end{array}$ & 12696625 \\
\hline 40 & 2004 & 62 & $\begin{array}{l}\text { Diagnostic value of hysterosalpingography in the detection of intrauterine abnormalities: A } \\
\text { comparison with hysteroscopy }\end{array}$ & 15505312 \\
\hline 41 & 2016 & 60 & $\begin{array}{l}\text { Autologous menstrual blood-derived stromal cells transplantation for severe Asherman's } \\
\text { syndrome }\end{array}$ & 27664218 \\
\hline 42 & 1981 & 58 & Gestational outcome following hysteroscopic lysis of adhesions & 6269905 \\
\hline 43 & 1988 & 58 & Endometrial abnormalities: evaluation with transvaginal sonography & 3275446 \\
\hline 44 & 2008 & 58 & $\begin{array}{l}\text { Office hysteroscopic early lysis of intrauterine adhesion after transcervical resection of } \\
\text { multiple apposing submucous myomas }\end{array}$ & 17686478 \\
\hline 45 & 2013 & 57 & Role of angiogenesis in the endometrial repair of patients with severe intrauterine adhesion & 23826415 \\
\hline 46 & 2014 & 57 & Effect of stem cell application on Asherman syndrome, an experimental rat model & 24974357 \\
\hline 47 & 2007 & 56 & Genital tuberculosis in Indian infertility patients & 17362955 \\
\hline 48 & 1984 & 54 & $\begin{array}{l}\text { Comparison of diagnostic accuracy of laparoscopy, hysteroscopy, and hysterosalpingogra- } \\
\text { phy in evaluation of female infertility }\end{array}$ & 6232154 \\
\hline 49 & 1999 & 54 & Transvaginal sonohysterographic evaluation of intrauterine adhesions & 10064410 \\
\hline 50 & 2012 & 52 & $\begin{array}{l}\text { The effect of collagen-binding vascular endothelial growth factor on the remodeling of } \\
\text { scarred rat uterus following full-thickness injury }\end{array}$ & 22136717 \\
\hline 51 & 2007 & 51 & Intrauterine adhesions as a risk factor for failed first-trimester pregnancy termination & 17900447 \\
\hline 52 & 2006 & 50 & $\begin{array}{l}\text { Successful use of vaginal sildenafil citrate in two infertility patients with Asherman's syn- } \\
\text { drome }\end{array}$ & 16724891 \\
\hline 53 & 1976 & 49 & Obstetric complications after treatment of intrauterine synechiae (Asherman's syndrome) & 934560 \\
\hline 54 & 2011 & 49 & $\begin{array}{l}\text { Efficacy of a polyethylene oxide-sodium carboxymethylcellulose gel in prevention of intrau- } \\
\text { terine adhesions after hysteroscopic surgery }\end{array}$ & 21777835 \\
\hline 55 & 1979 & 48 & Hysteroscopy in 100 patients & 437163 \\
\hline 56 & 2015 & 48 & $\begin{array}{l}\text { Randomized, controlled trial comparing the efficacy of intrauterine balloon and intrauter- } \\
\text { ine contraceptive device in the prevention of adhesion reformation after hysteroscopic } \\
\text { adhesiolysis }\end{array}$ & 25936237 \\
\hline 57 & 1966 & 47 & The pathology of postcurettage intrauterine adhesions & 5928449 \\
\hline 58 & 1998 & 47 & Myometrial scoring: a new technique for the management of severe Asherman's syndrome & 9591493 \\
\hline 59 & 2004 & 47 & $\begin{array}{l}\text { Hysteroscopy in the evaluation of patients with recurrent pregnancy loss - A cohort study in } \\
\text { a primary care population }\end{array}$ & 15809790 \\
\hline 60 & 2016 & 47 & $\begin{array}{l}\text { MicroRNA-29b inhibits endometrial fibrosis by regulating the Sp1-TGF-beta 1/Smad-CTGF } \\
\text { axis in a rat model }\end{array}$ & 26392347 \\
\hline 61 & 1981 & 45 & $\begin{array}{l}\text { Significance of intrauterine adhesions detected hysteroscopically in eumenorrheic infertile } \\
\text { women and role of antecedent curettage in their formation }\end{array}$ & 7468688 \\
\hline 62 & 1985 & 45 & $\begin{array}{l}\text { Etiology of cervical pregnancy. Association with abortion, pelvic pathology, IUDs and } \\
\text { Asherman's syndrome }\end{array}$ & 4038744 \\
\hline 63 & 2008 & 44 & Placenta accreta an association with fibroids and asherman syndrome & 18946102 \\
\hline 64 & 2014 & 44 & $\begin{array}{l}\text { Does cold loop hysteroscopic myomectomy reduce intrauterine adhesions? A retrospective } \\
\text { study }\end{array}$ & 24182410 \\
\hline 65 & 2011 & 43 & Outpatient hysteroscopy: a routine investigation before assisted reproductive techniques? & 20638055 \\
\hline
\end{tabular}


Table 1 (continued)

\begin{tabular}{|c|c|c|c|c|}
\hline Rank & Publication year & Total citation & Title & PMCID \\
\hline 66 & 2013 & 43 & $\begin{array}{l}\text { Creation of a female rabbit model for intrauterine adhesions using mechanical and infectious } \\
\text { injury }\end{array}$ & 23199550 \\
\hline 67 & 2012 & 42 & $\begin{array}{l}\text { Changes in endometrial receptivity in women with Asherman's syndrome undergoing hyst- } \\
\text { eroscopic adhesiolysis }\end{array}$ & 22535194 \\
\hline 68 & 1994 & 41 & $\begin{array}{l}\text { Post-abortion-hysteroscopy--a method for early diagnosis of congenital and acquired intrau- } \\
\text { terine causes of abortions }\end{array}$ & 7713291 \\
\hline 69 & 2015 & 41 & Results of centralized Asherman surgery, 2003-2013 & 26428306 \\
\hline 70 & 1992 & 40 & Hysteroscopic findings after missed abortion & 1521644 \\
\hline 71 & 1993 & 40 & Induced regeneration of endometrium following curettage for abortion: a comparative study & 8408501 \\
\hline 72 & 2007 & 40 & $\begin{array}{l}\text { Fluoroscopically guided synechiolysis for patients with Asherman's syndrome: menstrual } \\
\text { and fertility outcomes }\end{array}$ & 17109860 \\
\hline 73 & 1997 & 39 & $\begin{array}{l}\text { Successful treatment of severe uterine synechiae with transcervical resectoscopy combined } \\
\text { with laminaria tent }\end{array}$ & 9194644 \\
\hline 74 & 2005 & 39 & Pathologic findings in hysteroscopy before in vitro fertilization-embryo transfer (IVF-ET) & 16316847 \\
\hline 75 & 2014 & 39 & $\begin{array}{l}\text { Diagnostic accuracy of three-dimensional sonohysterography compared with office hysteros- } \\
\text { copy and its interrater/intrarater agreement in uterine cavity assessment after hysteroscopic } \\
\text { metroplasty }\end{array}$ & 24581576 \\
\hline 76 & 1989 & 38 & $\begin{array}{l}\text { Value of intrauterine device insertion and estrogen administration after hysteroscopic metro- } \\
\text { plasty }\end{array}$ & 2549238 \\
\hline 77 & 2008 & 38 & $\begin{array}{l}\text { Thin unresponsive endometrium-a possible complication of surgical curettage compromis- } \\
\text { ing ART outcome }\end{array}$ & 18797990 \\
\hline 78 & 1983 & 37 & Diagnosis and treatment of intrauterine adhesions by microhysteroscopy & 6825866 \\
\hline 79 & 2017 & 37 & $\begin{array}{l}\text { Prevalence of intrauterine adhesions after the application of hyaluronic acid gel after dilata- } \\
\text { tion and curettage in women with at least one previous curettage: short-term outcomes of a } \\
\text { multicenter, prospective randomized controlled trial }\end{array}$ & 28390688 \\
\hline 80 & 2018 & 37 & $\begin{array}{l}\text { Allogeneic cell therapy using umbilical cord MSCs on collagen scaffolds for patients with } \\
\text { recurrent uterine adhesion: a phase I clinical trial }\end{array}$ & 29996892 \\
\hline 81 & 2010 & 36 & Results of 2500 office-based diagnostic hysteroscopies before IVF & 20207586 \\
\hline 82 & 2017 & 36 & $\begin{array}{l}\text { Reproductive outcomes in patients with intrauterine adhesions following hysteroscopic } \\
\text { adhesiolysis: experience from the largest women's hospital in China }\end{array}$ & 27856386 \\
\hline 83 & 2017 & 36 & $\begin{array}{l}\text { Effects of Aspirin and intrauterine balloon on endometrial repair and reproductive prognosis } \\
\text { in patients with severe intrauterine adhesion: a prospective cohort study }\end{array}$ & 28251159 \\
\hline 84 & 1976 & 35 & $\begin{array}{l}\text { Intrauterine adhesions secondary to elective abortion. Hysteroscopic diagnosis and manage- } \\
\text { ment }\end{array}$ & \\
\hline 85 & 1992 & 35 & Diagnostic hysteroscopy: its value in an in-vitro fertilization/embryo transfer unit & 1291572 \\
\hline 86 & 1996 & 35 & Hysteroscopic management of uterine synechiae: a series of 102 observations & 8730623 \\
\hline 87 & 1999 & 35 & Fluoroscopically guided hysteroscopic division of adhesions in severe Asherman syndrome & 10362178 \\
\hline 88 & 2000 & 35 & $\begin{array}{l}\text { Operative hysteroscopy for infertility using normal saline solution and a coaxial bipolar } \\
\text { electrode: a pilot study }\end{array}$ & 10920101 \\
\hline 89 & 2007 & 35 & Prevalence of uterine synechia after abortion evacuation curettage & 18094891 \\
\hline 90 & 2008 & 35 & Genital tuberculosis: an important cause of Asherman's syndrome in India & 17653564 \\
\hline 91 & 2016 & 35 & $\begin{array}{l}\text { Endometrial stem cells repair injured endometrium and induce angiogenesis via AKT and } \\
\text { ERK pathways }\end{array}$ & 27486270 \\
\hline 92 & 2015 & 34 & Preventive effect of oral mucosal epithelial cell sheets on intrauterine adhesions & 25475585 \\
\hline 93 & 2007 & 33 & Hysteroscopy after uterine fibroid embolization in women of fertile age & 17578361 \\
\hline 94 & 2016 & 33 & $\begin{array}{l}\text { The influence of the location and extent of intrauterine adhesions on recurrence after hyst- } \\
\text { eroscopic adhesiolysis }\end{array}$ & 25753391 \\
\hline 95 & 2017 & 33 & $\begin{array}{l}\text { Human amniotic mesenchymal stromal cell transplantation improves endometrial regenera- } \\
\text { tion in rodent models of intrauterine adhesions }\end{array}$ & 28285950 \\
\hline 96 & 1982 & 32 & Asherman's syndrome. A comparison of therapeutic methods & 7120210 \\
\hline 97 & 1995 & 31 & $\begin{array}{l}\text { Preoperative sonographic measurement of endometrial pattern predicts the outcome of } \\
\text { surgical repair in patients with severe Asherman's syndrome }\end{array}$ & 7843453 \\
\hline 98 & 1996 & 31 & Intrauterine adhesions: detection with transvaginal US & 8638001 \\
\hline
\end{tabular}


Table 1 (continued)

\begin{tabular}{|c|c|c|c|c|}
\hline Rank & Publication year & Total citation & Title & PMCID \\
\hline 99 & 1999 & 31 & $\begin{array}{l}\text { Total corporal synechiae due to tuberculosis carry a very poor prognosis following hystero- } \\
\text { scopic synechialysis }\end{array}$ & 10438408 \\
\hline 100 & 1997 & 30 & Simplified therapy for Asherman's syndrome & 9418695 \\
\hline
\end{tabular}

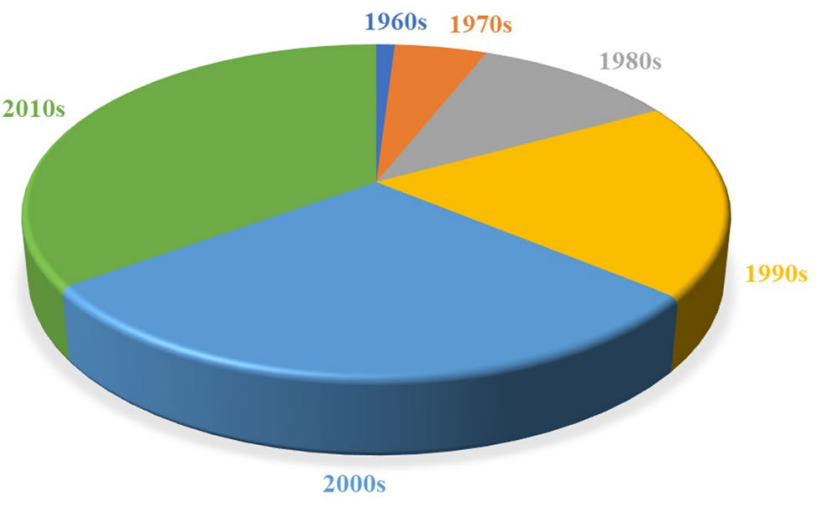

TOTAL $=100$

Figure 2 Time distribution of top 100 most-cited articles in intrauterine adhesion

of IUA, understanding the disease mechanism is also crucial to the treatment of the disease. Recently, the number of studies published concerning the mechanism of IUA has been on the rise, and findings from these and similar studies may suggest novel directions for clinical research.

In contrast to the trend of other bibliometric analysis reports, articles originating from the USA and developed countries did not have the largest number of papers. China and the USA were both important sources of articles, publishing 19 and 18 articles, respectively. Furthermore, 33\% of the 100 most cited papers were from developing countries, and $67 \%$ were from developed countries. There are several reasons for this: (1) The clinical manifestations of IUA were first reported in the USA in the nineteenth century and later defined and named by American doctors. Therefore, they were able to study it earlier and more systematically [40]. Furthermore, the USA and other developed countries had the requisite funding to support scientific research. The sharing of these research results will help research into IUA [41, 42]; (2) The occurrence of IUA is closely related to abortion and curettage, and abortion is illegal in many developing countries due to religious beliefs. In developed countries, the rate of abortion dropped by $19 \%$ from 1990 to 2014, while it only fell by $2 \%$ in developing countries over the same period [43]. Moreover, least-safe abortions accounted for the largest proportion of abortions in developing countries [44]. Thus, IUA is more likely to be an issue in developing countries, and such concern emerged as the research focus. (3) China and other developing countries have large populations. As the promotion and popularization of contraceptive measures in these populations are typically inadequate, unintended pregnancies and thus election of surgical abortion may be more common. Repeated or informal intrauterine operations can ultimately lead to irreversible damage to the endometrium [45, 46]. (4) After China introduced the 2-child policy, the incidence of IUA and the number of cases of recurrent IUA requiring treatment grew [47, 48]. IUA is a universal disease; however, nowhere in these 100 most cited papers was a multinational cooperative initiative mentioned.

Our results indicated that the journals that published the identified articles did not have high impact factors. This is likely because these papers were rarely published in comprehensive journals, and the impact factors of professional
Figure 3 Time-dependent citation density trend of the 100 most-cited articles in intrauterine adhesion

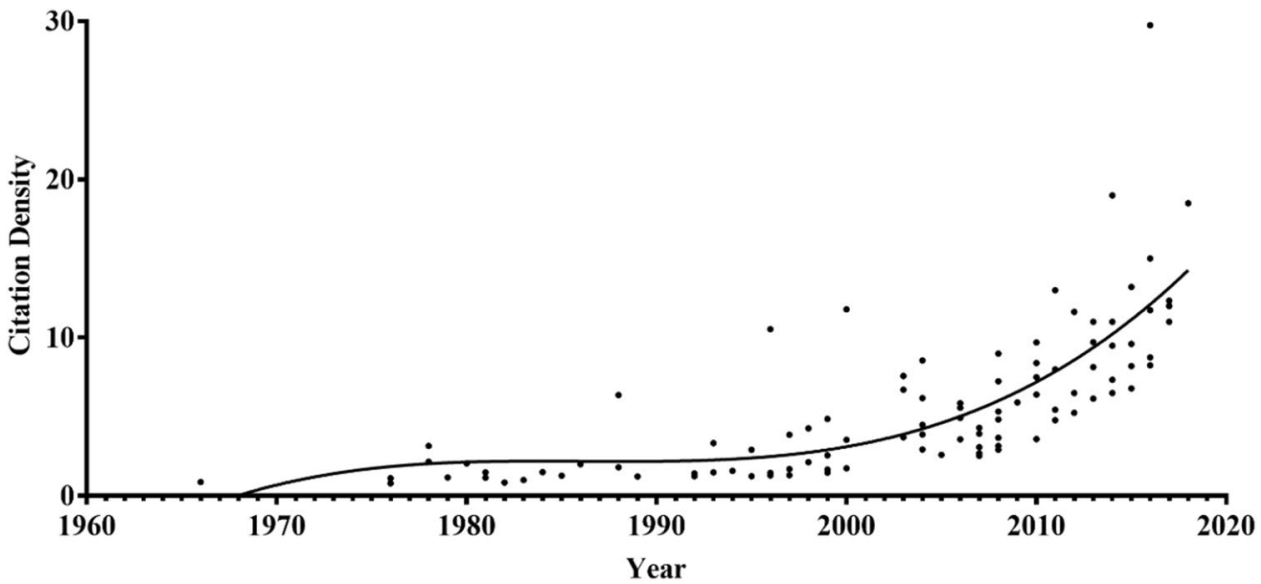


Figure 4 Country of origin of the top 100 most-cited articles in intrauterine adhesion

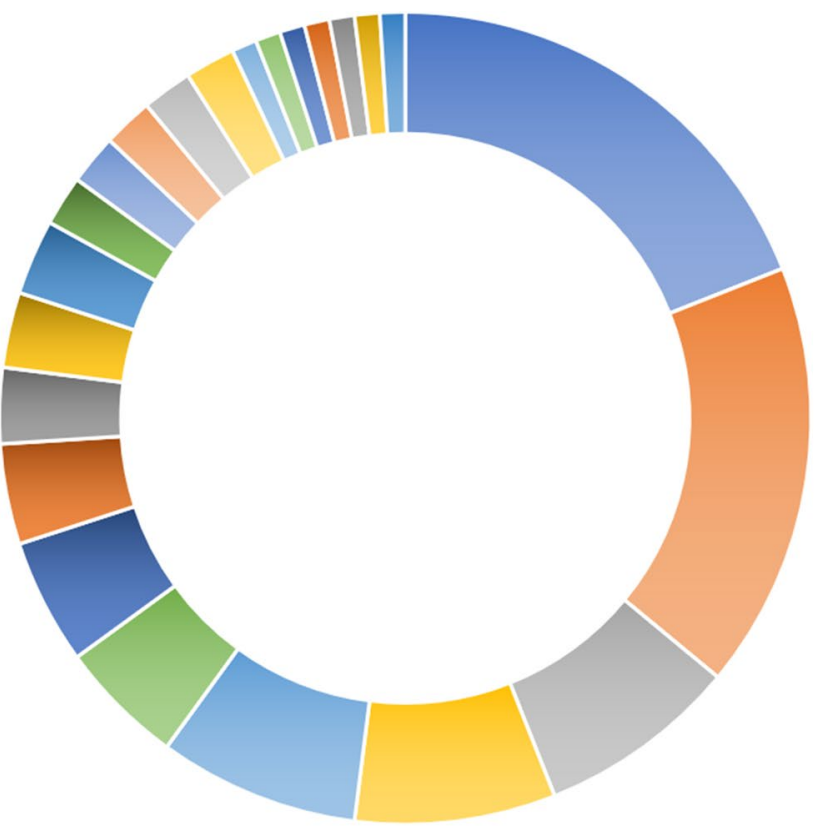

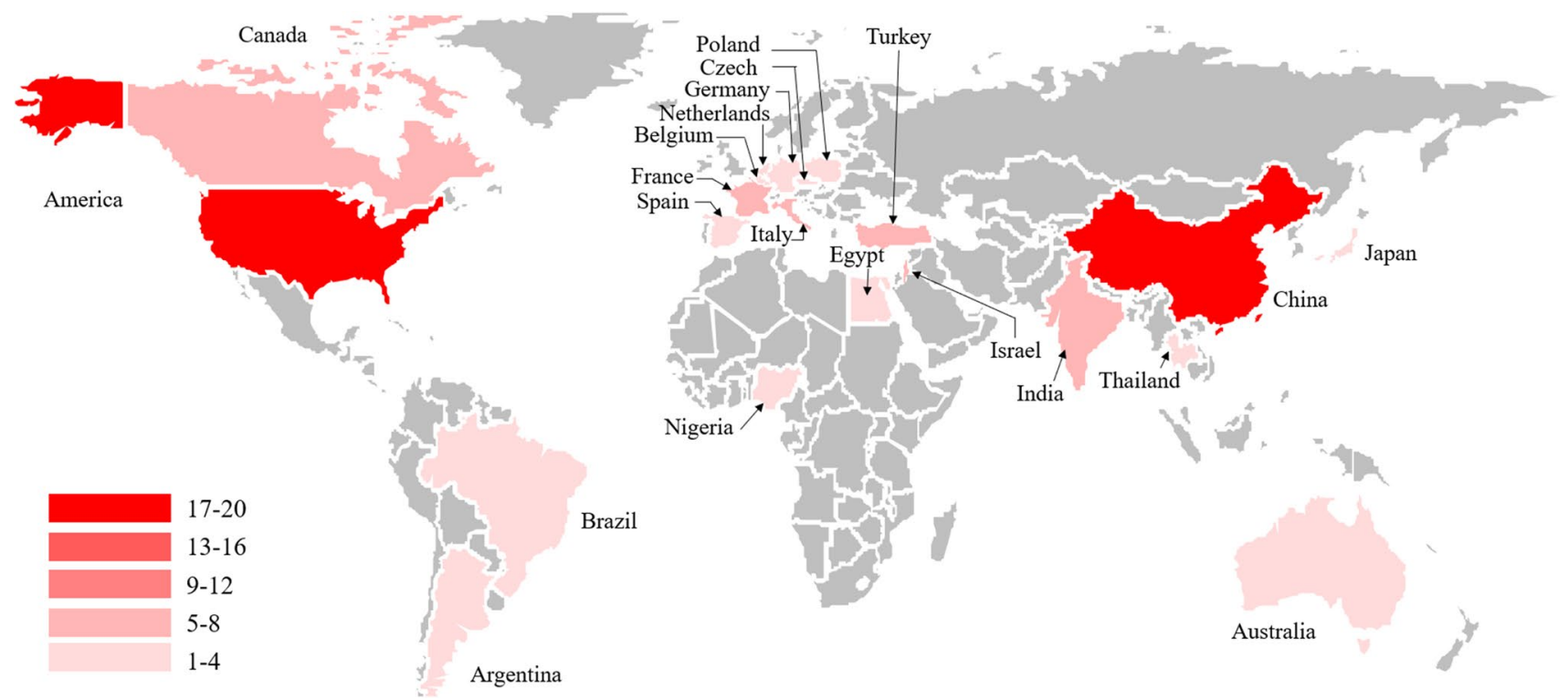

Figure 5 Geographical distribution of the 100 top most-cited articles in intrauterine adhesion

obstetrics and gynecology journals are relatively low. This result highlights a growing tendency of researchers perhaps preferring to publish articles in influential professional journals. However, there is no denying that the value of IUA research has not been fully appreciated.

Nearly $50 \%$ of the 100 papers were issued in 2 journals, Fertility and Sterility and Human Reproduction, followed closely by 2 prominent journals in the field of obstetrics and gynecology, American Journal of Obstetrics and Gynecology and Obstetrics and Gynecology. This demonstrates that IUA was of particular concern in the field of reproductive medicine. Among the 100 most cited articles, the themes of papers published in recent years appeared to be more diverse. They included, for example, a phase I clinical study of autologous stem cell transplantation for the treatment of IUA published in Stem Cell Research \& Therapy [49] and a collagen scaffold for endometrial regeneration study published in Biomaterials [50].

Among the authors of the 100 most cited papers, we found that 2 researchers contributed 3 articles. One of these authors was Charles M. March from the USA. His articles were all published before 1990 and emphasized hysteroscopy 
Table 2 Journals of the 100 top-cited studies published

\begin{tabular}{|c|c|c|c|c|}
\hline Publication & $\begin{array}{l}\text { Number } \\
\text { account }\end{array}$ & Total citation & $\begin{array}{l}\text { Average cita- } \\
\text { tion }\end{array}$ & IF (2020) \\
\hline Fertility and Sterility & 27 & 1895 & 70 & 6.3 \\
\hline Human Reproduction & 16 & 1171 & 73 & 5.7 \\
\hline American Journal of Obstetrics and Gynecology & 6 & 602 & 100 & 6.5 \\
\hline Journal of Minimally Invasive Gynecology & 5 & 310 & 62 & 3.1 \\
\hline Obstetrics and Gynecology & 4 & 187 & 47 & 5.5 \\
\hline Archives of Gynecology and Obstetrics & 3 & 174 & 58 & 2.3 \\
\hline European Journal of Obstetrics, Gynecology, and Reproductive Biology & 3 & 153 & 51 & 1.9 \\
\hline International Journal of Gynecology \& Obstetrics & 3 & 236 & 79 & 2.2 \\
\hline Journal of Obstetrics and Gynaecology Research & 3 & 178 & 59 & 1.4 \\
\hline The Journal of Reproductive Medicine & 3 & 115 & 38 & 0.2 \\
\hline Blog-An International Journal of Obstetrics and Gynaecology & 2 & 97 & 49 & 4.7 \\
\hline Journal of Assisted Reproduction and Genetics & 2 & 95 & 48 & 2.8 \\
\hline Reproductive Biomedicine Online & 2 & 108 & 54 & 3.2 \\
\hline Ajr. American Journal of Roentgenology & 1 & 58 & 58 & 3.0 \\
\hline American Journal of Roentgenology & 1 & 62 & 62 & 3.0 \\
\hline Biomaterials & 1 & 52 & 52 & 10.3 \\
\hline Biomed Research International & 1 & 36 & 36 & 2.3 \\
\hline Contraception & 1 & 51 & 51 & 2.8 \\
\hline Cytotherapy & 1 & 33 & 33 & 4.2 \\
\hline Gynecological Endocrinology & 1 & 39 & 39 & 1.6 \\
\hline International Journal of Clinical and Experimental Pathology & 1 & 57 & 57 & 0.3 \\
\hline Journal of Human Reproductive Sciences & 1 & 54 & 54 & 0.8 \\
\hline Journal of Clinical Ultrasound & 1 & 117 & 117 & 1.0 \\
\hline Journal of Surgical Research & 1 & 43 & 43 & 1.8 \\
\hline Journal of Ultrasound In Medicine & 1 & 44 & 44 & 1.8 \\
\hline Journal of Womens Health & 1 & 50 & 50 & 1.9 \\
\hline Jsls: Journal of The Society of Laparoendoscopic Surgeons & 1 & 99 & 99 & 1.5 \\
\hline Plos One & 1 & 114 & 114 & 2.7 \\
\hline Radiology & 1 & 31 & 31 & 7.9 \\
\hline Reproduction & 1 & 35 & 35 & 3.2 \\
\hline Reproductive Sciences & 1 & 47 & 47 & 2.6 \\
\hline Sao Paulo Medical Journal & 1 & 35 & 35 & 1.0 \\
\hline Stem Cell Research \& Therapy & 1 & 37 & 37 & 5.1 \\
\hline Surgical Endoscopy and Other Interventional Techniques & 1 & 47 & 47 & 3.1 \\
\hline
\end{tabular}

as the gold standard for the diagnosis and classification of IUA and hysteroscopic adhesiolysis as the first choice for the treatment of IUA [51-53]. The other author was Jehn-Hsiahn Yang from Taiwan, China, who is from a younger generation of researchers. The similarity with March was a focus on hysteroscopy. Yang's 3 articles asserted that IUA is a common complication after transcervical resection of multiple apposing submucous myomas [54], the formation of new adhesions after hysteroscopic adhesiolysis affects endometrial repair [55], and the location and area of adhesions are important factors that affect the recurrence of IUA [15].

Among the 100 articles, the level of evidence was between I and V. The overall distribution was average, with level II being relatively high, which is different from other bibliometric studies. This may be attributable to the design of clinical trials. Treatment of IUA is closely related to patients' reproductive prognosis, and for women, age is also a significant factor. Therefore, considering the effect of placebo control on patients, experimental studies are mostly unilateral. In the future, with the increase in the demand for childbirth and the introduction of 2 or even 3 -child policies in some countries, it is expected that the rate of research into hysteroscopic adhesiolysis, postoperative adjuvant treatment, and related subjects will rapidly increase.

We also studied the thematic distribution of articles. The adjuvant treatment of IUA ranked first, followed by the 
Table 3 List of first authors with frequent articles within the top-cited list

\begin{tabular}{|c|c|c|c|}
\hline First Author & $\begin{array}{l}\text { Number } \\
\text { of Stud- } \\
\text { ies }\end{array}$ & $\begin{array}{l}\text { Citations } \\
\text { Account }\end{array}$ & Author's Affiliation \\
\hline C M March & 3 & 226 & $\begin{array}{l}\text { Department of Obstetrics and Gynecology, University of Southern California School of Medicine Los } \\
\text { Angeles, California, USA. }\end{array}$ \\
\hline Jehn-Hsiahn Yang & 3 & 159 & $\begin{array}{l}\text { Department of Obstetrics and Gynecology, National Taiwan University Hospital and National Taiwan } \\
\text { University College of Medicine, Taipei, Taiwan. }\end{array}$ \\
\hline R F Valle & 2 & 286 & $\begin{array}{l}\text { Department of Obstetrics and Gynecology, Northwestern University Medical School, Chicago, Illi- } \\
\text { nois, USA }\end{array}$ \\
\hline Mohamed I Amer & 2 & 157 & Department of Obstetrics and Gynecology, Ain Shams University, Cairo, Egypt. \\
\hline Recai Pabuccu & 2 & 153 & Department of Obstetrics and Gynecology, Gülhane School of Medicine, Ankara, Turkey. \\
\hline Xiaona Lin & 2 & 125 & $\begin{array}{l}\text { Center of Reproductive Medicine, Sir Run Run Shaw Hospital, School of Medicine, Zhejiang Univer- } \\
\text { sity, PR China. }\end{array}$ \\
\hline H Fernandez & 2 & 113 & Department of Obstetrics and Gynaecology, Antoine Béclère Hospital, Clamart Cedex, France. \\
\hline Yuqing Chen & 2 & 93 & $\begin{array}{l}\text { Department of Obstetrics and Gynecology, The First Affiliated Hospital of Sun Yat-sen University, } \\
\text { Guangzhou, China. }\end{array}$ \\
\hline P J Taylor & 2 & 93 & $\begin{array}{l}\text { Department of Obstetrics and Gynecology, University of Calgary and Foothills Hospital, Calgary, } \\
\text { Alberta, Canada }\end{array}$ \\
\hline A Golan & 2 & 75 & Department of Obstetrics and Gynecology, Assaf Harofeh Medical Center, Zerifin, Israel. \\
\hline
\end{tabular}

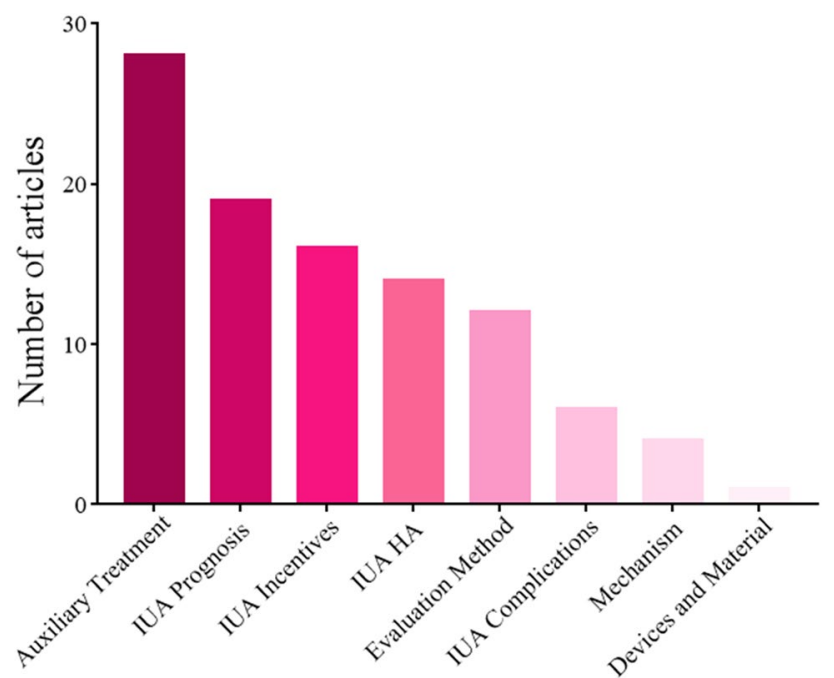

Theme

Figure 6 The thematic distribution of the 100 top most-cited articles in intrauterine adhesion

prognosis of reproductive outcome after hysteroscopic adhesiolysis, the incentive factors of IUA, hysteroscopic adhesiolysis, and the evaluation method of IUA. Hysteroscopic adhesiolysis is the primary treatment method for IUA. However, how to improve the therapeutic effect through drugs and biological agents after the surgery has been a problem that researchers have sought to overcome in recent years [56]. Network analysis of the authors' keywords or subject terms was conducted in 2 periods of publication: in the 2000s (34 articles) and the 2010s (30 articles). The result indicated that "hysteroscopy", "hysteroscopic adhesiolysis",

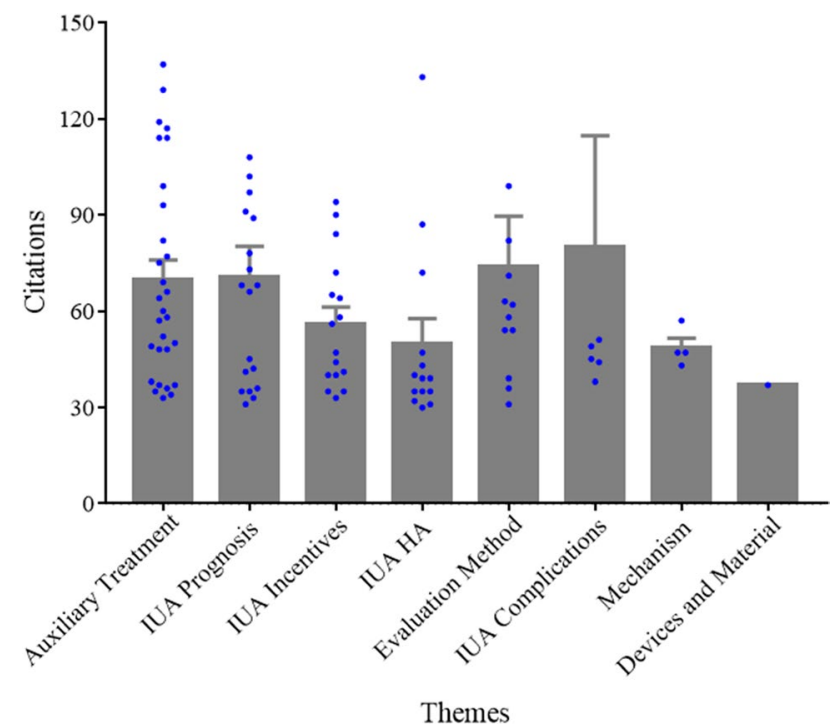

Figure 7 Mean citation per article based on the theme

"infertility", and "reproductive outcome" were highly centralized in both 2000s and 2010s, and "placental implantation" was highly concentrated in the 2000s. This was consistent with the research trend in recent years. However, the topic of IUA prevention presented a blank state in the highly cited papers, indicating that breakthroughs in early prevention are urgently needed in this field.

Researchers have gradually realized that even if patients with IUA succeed in conception, there remain many risks of pregnancy complications. The most cited article in this study was also an article about IUA complications, in which the author proposed that patients with IUA were associated 


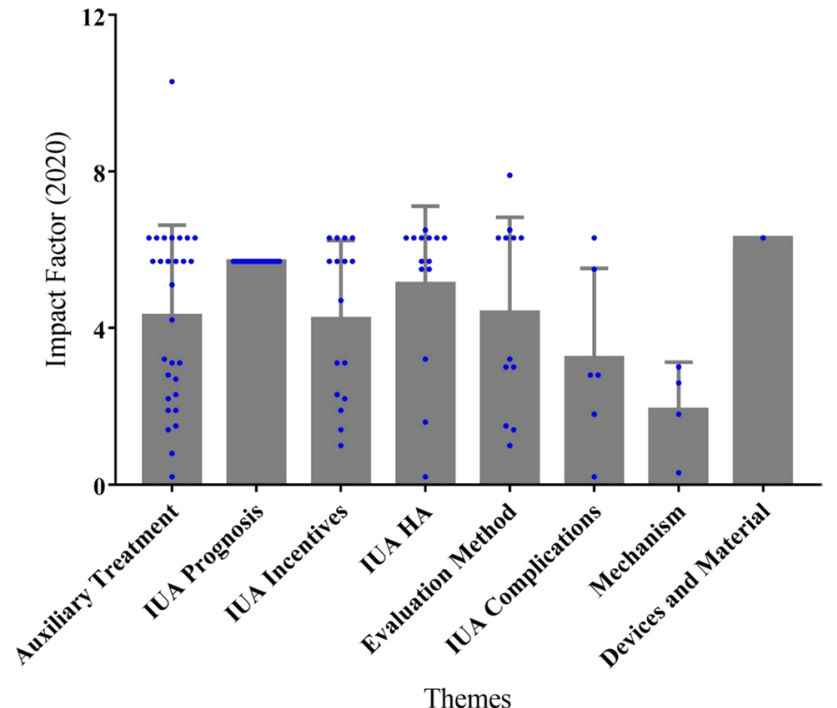

Figure 8 Mean impact factor per article based on the theme

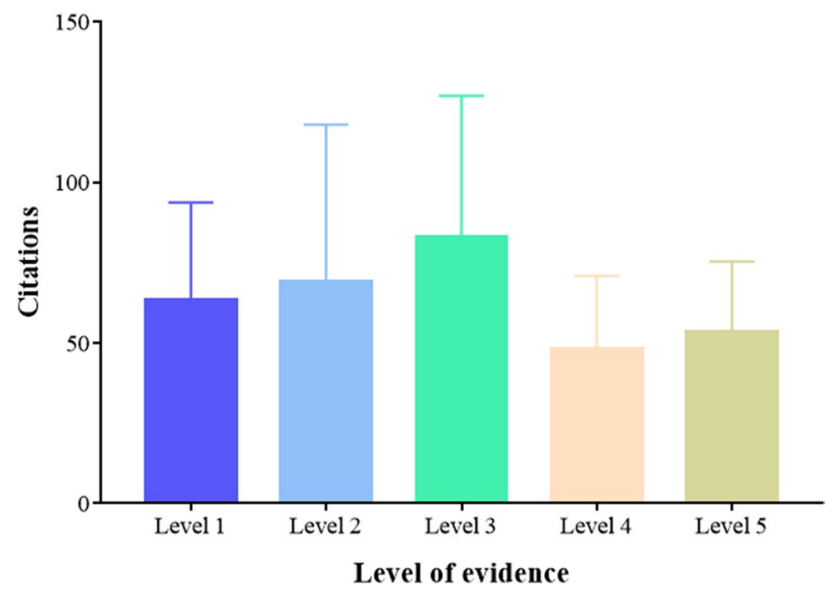

Figure 9 Mean citation per article based on level of evidence

with many risks during pregnancy. In analyzing the citation density of papers published in the 2010s, we found that each theme was evenly distributed. In analyzing the impact factor under each theme, it could be seen that articles related to devices and materials were relatively high, while research on mechanisms was relatively low. Stem cell and fibrosis were highly concentrated in the 2010s. In recent years, researchers have paid increasing attention to the effectiveness of adjuvant therapy after hysteroscopic adhesiolysis in suppressing the reformation of adhesion and promoting endometrial regeneration [57]. Previous research focused on the placement of uterine stents, Foley catheters, hyaluronic acid, or hormone replacement therapy [58]. Nevertheless, more importance was attached to biotherapy, especially in the field of stem cell therapy. Bone marrow mesenchymal stem cells (BMSCs) [59], umbilical cord mesenchymal stem cells (UCMSCs) [60], and menstrual blood mesenchymal stem cells (MbMSCs) [61, 62] have been used clinically in patients with IUA, resulting in an improvement in reproductive outcome. Furthermore, researchers reported that stem cells could not only promote endometrial cell proliferation, but also inhibit the process of fibrosis [63].

In 2020, a review gathered the controversial views of different researchers on the treatment of IUA [64]. One perspective advocated that the adjuvant treatment after the surgery should be given more attention, and another suggested that IUA be treated with multiple operations. However, hysteroscopic adhesiolysis has always been the center of research over the years, and discussions concerning surgical methods and surgical techniques are still sparse [65]. It is undeniable that combined adjuvant treatment after surgery is the dominant trend of IUA treatment.

This analysis does generate some valuable information, but some limitations should be mentioned. First, the citation analysis was mainly based on the Web of Science, and the number of citations may be misleading. Meanwhile, we might have missed some important papers that were not included in the Science Citation Index database. Second, we might have overlooked the newly published articles that were meaningful in this area but have yet to reach high citation levels due to the criterion that the number of citations sorted papers. Overall, our analysis was by no means exhaustive, but the list of most cited articles still includes many influential papers in the field of IUA.

\section{Conclusion}

This article highlights the top 100 most cited articles in IUA research published over the last 70 years, including their publication time and regional centers, first author, level of evidence, and research theme. Furthermore, our findings support the notion that postoperative adjuvant therapy has played a key role in the field of IUA, and more and more basic and clinical studies are now exploring suitable and effective adjuvant treatments for IUA. Meanwhile, the method and techniques of surgical therapy have been controversial. Regardless, the current prognosis of IUA remains extremely poor, and many difficult challenges need to be overcome. Researchers have concentrated their focus on clinical trials rather than on basic laboratory research. Thus, the foremost difficulty lies in addressing the limited understanding of the underlying mechanisms of adhesion formation in the uterus and the other influencing factors. 


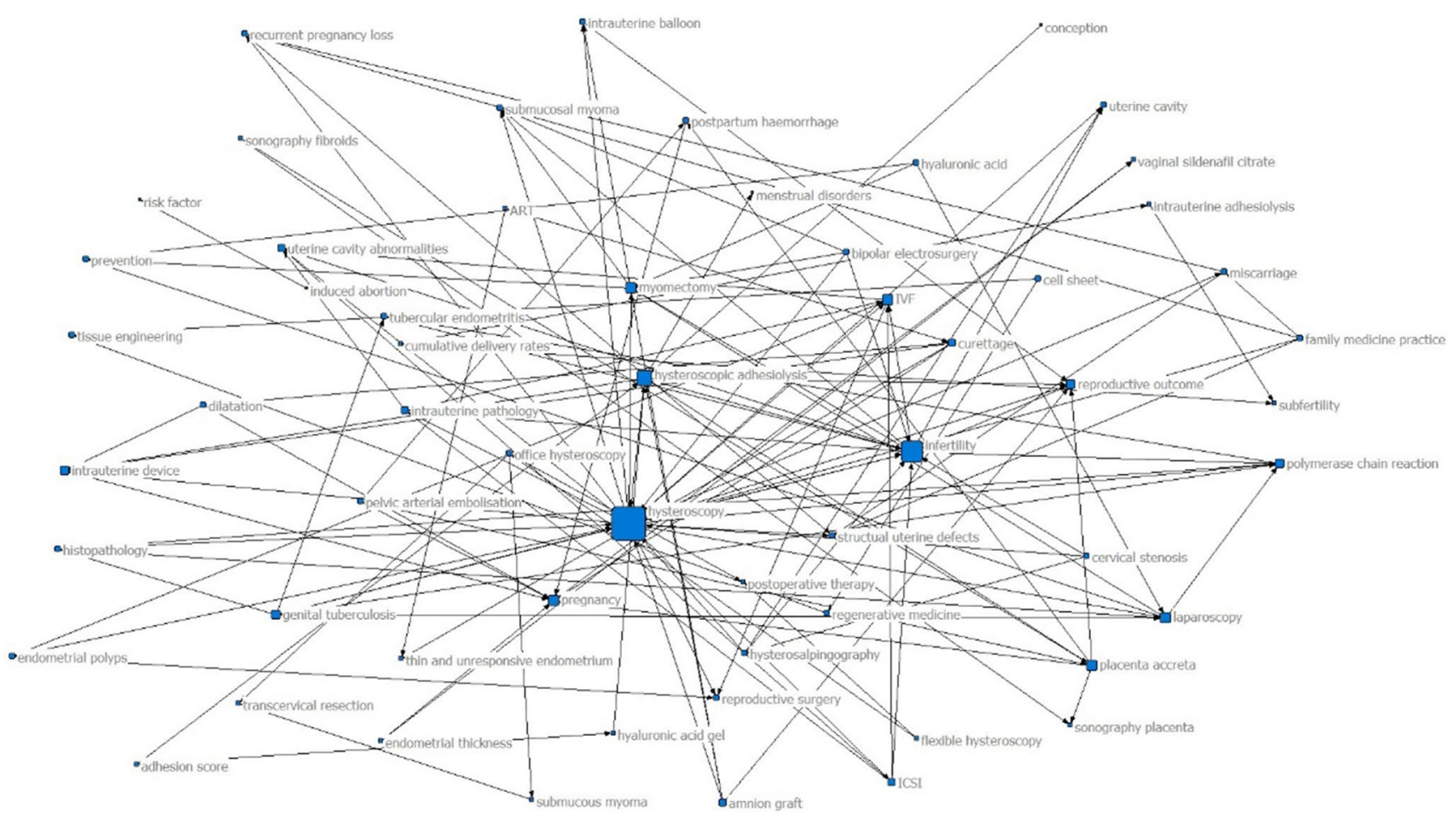

Figure 10 Degree centrality analysis in the 2000s (34 articles)

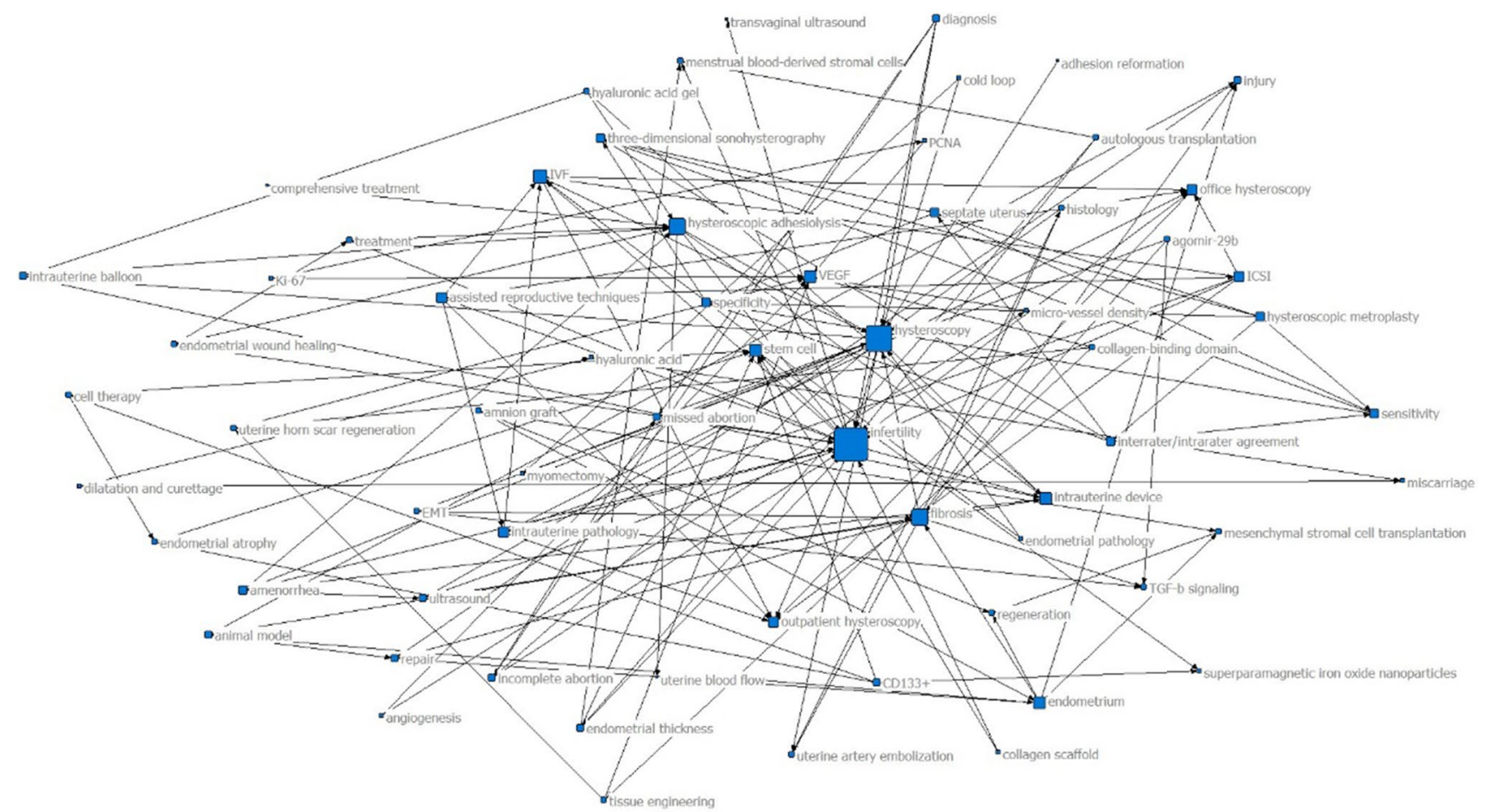

Figure 11 Degree centrality analysis in the 2010s (30 articles) 
Abbreviations IUA: Intrauterine adhesion; IUD: Intrauterine device; ACP: Auto-crosslinked hyaluronic acid; BMSC: Bone marrow mesenchymal stem cell; UCMSC: Umbilical cord mesenchymal stem cell; MbMSC: Menstrual blood mesenchymal stem cell

Author contribution DX contributed to the design of the study. DX and $\mathrm{XZ}$ revised the manuscript. PG and WL contributed to the process of searching and selecting articles and drafting the manuscript.

Funding This study was supported by the National Key Research and Development Program of China (grant no. 2018YFC1004800).

Data availability Not applicable

Code availability Not applicable

\section{Declarations}

Ethics approval and consent to participate Not applicable

Consent to participate Not applicable

Consent for publication Not applicable

Competing interests The authors declare no competing interests.

Open Access This article is licensed under a Creative Commons Attribution 4.0 International License, which permits use, sharing, adaptation, distribution and reproduction in any medium or format, as long as you give appropriate credit to the original author(s) and the source, provide a link to the Creative Commons licence, and indicate if changes were made. The images or other third party material in this article are included in the article's Creative Commons licence, unless indicated otherwise in a credit line to the material. If material is not included in the article's Creative Commons licence and your intended use is not permitted by statutory regulation or exceeds the permitted use, you will need to obtain permission directly from the copyright holder. To view a copy of this licence, visit http://creativecommons.org/licenses/by/4.0/.

\section{References}

1. Asherman JG. Traumatic intra-uterine adhesions. J Obstet Gynaecol Br Emp. 1950;57:892-6.

2. Wang Y, Yao Z, Zhao H, Yue C, Yu Q, Zhang Y, Guo Z, Xu Z, Zhang L, Yan L. Reproductive outcomes of in vitro fertilizationintracytoplasmic sperm injection after transcervical resection of adhesions: a retrospective cohort study. J Minim Invasive Gynecol. 2020. https://doi.org/10.1016/j.jmig.2020.10.029.

3. Hooker AB, de Leeuw RA, Twisk JWR, Brölmann HAM, Huirne JAF. Reproductive performance of women with and without intrauterine adhesions following recurrent dilatation and curettage for miscarriage: long-term follow-up of a randomized controlled trial. Hum Reprod. 2020. https://doi.org/10.1093/humrep/deaa289.

4. Chawla L, Prateek S, Bahadur A, Durgapal P. Intrauterine adhesions with secondary amenorrhea: A notable indicator of endometrial tuberculosis. Indian J Tuberc. 2020;67:575-7.

5. March CM. Management of Asherman's syndrome. Reprod Biomed Online. 2011;23:63-76.

6. Wang L, Yu C, Chang T, Zhang M, Song S, Xiong C, Su P and Xiang W. In situ repair abilities of human umbilical cord-derived mesenchymal stem cells and autocrosslinked hyaluronic acid gel complex in rhesus monkeys with intrauterine adhesion. Sci Adv. 2020;6; eaba6357.

7. Diamond MP, Freeman ML. Clinical implications of postsurgical adhesions. Hum Reprod Update. 2001;7:567-76.

8. Zhang LP, Wang M, Shang X, Zhang Q, Yang BJ, Xu Y, Li JH, Feng LM. The incidence of placenta related disease after the hysteroscopic adhesiolysis in patients with intrauterine adhesions. Journal. 2020;59:575-9.

9. Baradwan S, Baradwan A, Bashir M and Al-Jaroudi D. The birth weight in pregnant women with Asherman syndrome compared to normal intrauterine cavity: A case-control study. Medicine (Baltimore). 2018;97(32);e11797.

10. Abbott J, Deans R. Accelerating the science after 125 years of treating intrauterine adhesions. Journal. 2020. https://doi.org/10. 1016/j.jmig.2020.12.028.

11. Stamenov GS, Vitale SG, Della Corte L, Vilos GA, Parvanov DA, Nikolova DN, Ganeva RR and Haimovich S. Hysteroscopy and female infertility: a fresh look to a busy corner. Hum Fertil (Camb). 2020;1-29.

12. Yu D, Wong Y-M, Cheong Y, Xia E, Li T-C. Asherman syndrome-one century later. Fertil Steril. 2008;89:759-79.

13. Li C, Cai A, Sun C, Wu B, Chen X, Mao Y, Zhang Y, Gou Y, Yu J, Wang Y, Yu H, Wang J. The study on the safety and efficacy of amnion graft for preventing the recurrence of moderate to severe intrauterine adhesions. 2020;7;266-71.

14. Chen L, Zhang H, Wang Q, Xie F, Gao S, Song Y, Dong J, Feng H, Xie K, Sui L. Reproductive outcomes in patients with intrauterine adhesions following hysteroscopic adhesiolysis: experience from the largest women's hospital in China. Journal. 2017;24:299-304.

15. Yang JH, Chen CD, Chen SU, Yang YS, Chen MJ. The influence of the location and extent of intrauterine adhesions on recurrence after hysteroscopic adhesiolysis. Journal. 2016;123:618-23.

16. Doroftei B, Dabuleanu AM, Ilie OD, Maftei R, Anton E, Simionescu G, Matei T and Armeanu T. Mini-Review of the New Therapeutic Possibilities in Asherman Syndrome-Where Are We after One Hundred and Twenty-Six Years? Diagnostics (Basel). 2020;10(9):706.

17. Di Guardo F, Della Corte L, Vilos GA, Carugno J, Török P, Giampaolino P, Manchanda R and Vitale SG. Evaluation and treatment of infertile women with Asherman syndrome: an updated review focusing on the role of hysteroscopy. Reprod Biomed Online. 2020;41(1);55-61.

18. Capmas P, Mihalache A, Duminil L, Hor LS, Pourcelot AG and Fernandez H. Intrauterine adhesions: What is the pregnancy rate after hysteroscopic management? J Gynecol Obstet Hum Reprod. 2020;49(7);101797.

19. Huang XW, Lin MM, Zhao HQ, Powell M, Wang YQ, Zheng RR, Ellis LB, Xia WT, Lin F. A prospective randomized controlled trial comparing two different treatments of intrauterine adhesions. Reprod Biomed Online. 2020;40:835-41.

20. Yang X, Liu Y, Li TC, Xia E, Xiao Y, Zhou F, Song D, Zhou Q. Durations of intrauterine balloon therapy and adhesion reformation after hysteroscopic adhesiolysis: a randomized controlled trial. Reprod Biomed Online. 2020;40:539-46.

21. Zhou Q, Shi X, Saravelos S, Huang X, Zhao Y, Huang R, Xia E, $\mathrm{Li}$ TC. Auto-cross-linked hyaluronic acid gel for prevention of intrauterine adhesions after hysteroscopic adhesiolysis: a randomized controlled trial. J Minim Invasive Gynecol. 2020. https:// doi.org/10.1016/j.jmig.2020.06.030.

22. Zheng F, Xin X, He F, Liu J, Cui Y. Meta-analysis on the use of hyaluronic acid gel to prevent intrauterine adhesion after intrauterine operations. Exp Ther Med. 2020;19:2672-8.

23. Yao Q, Zheng YW, Lan QH, Wang LF, Huang ZW, Chen R, Yang $\mathrm{Y}, \mathrm{Xu} \mathrm{HL}$, Kou L and Zhao YZ. Aloe/poloxamer hydrogel as an injectable $\beta$-estradiol delivery scaffold with multi-therapeutic 
effects to promote endometrial regeneration for intrauterine adhesion treatment. Eur J Pharm Sci. 2020;148;105316.

24. Huberlant S, Leprince S, Allegre L, Warembourg S, Leteuff I, Taillades H, Garric X, de Tayrac R, Letouzey V. In vivo evaluation of the efficacy and safety of a novel degradable polymeric film for the prevention of intrauterine adhesions. J Minim Invasive Gynecol. 2020. https://doi.org/10.1016/j.jmig.2020.10.025.

25. Kaczynski P, Bauersachs S, Goryszewska E, Baryla M, Waclawik A. Synergistic action of estradiol and PGE2 on endometrial transcriptome in vivo resembles pregnancy effects better than estradiol alone $\dagger$. Biol Reprod. 2020. https://doi.org/10.1093/biolre/ ioaa230.

26. Chang Y, Duan H, Shen X, Wang S, Guo Z, Chen S. Controversy in the management of oestrogen therapy before hysteroscopic adhesiolysis: a systematic review and meta-analysis. Reprod Biomed Online. 2020;41:715-23.

27. Li J, Huang B, Dong L, Zhong Y and Huang Z. WJ-MSCs intervention may relieve intrauterine adhesions in female rats via TGF-\&beta;1-mediated Rho/ROCK signaling inhibition. Mol Med Rep. 2021;23(1):8.

28. Xin L, Lin X, Zhou F, Li C, Wang X, Yu H, Pan Y, Fei H, Ma L, Zhang S. A scaffold laden with mesenchymal stem cell-derived exosomes for promoting endometrium regeneration and fertility restoration through macrophage immunomodulation. Acta Biomater. 2020;113:252-66.

29. Park M, Hong SH, Park SH, Kim YS, Yang SC, Kim HR, Noh S, Na S, Lee HK, Lim HJ, Lyu SW, Song H. Perivascular stem cell-derived cyclophilin A improves uterine environment with Asherman's syndrome via HIF1 $\alpha$-dependent angiogenesis. Mol Ther. 2020;28:1818-32.

30. Tan Q, Xia D, Ying X. miR-29a in Exosomes from bone marrow mesenchymal stem cells inhibit fibrosis during endometrial repair of intrauterine adhesion. Int J Stem Cells. 2020;13:414-23.

31. Ouyang X, You S, Zhang Y, Zhang C, Zhang G, Shao X, He F, $\mathrm{Hu}$ L. Transplantation of human amnion epithelial cells improves endometrial regeneration in rat model of intrauterine adhesions. Stem Cells Dev. 2020;29:1346-62.

32. Lin X, Zhang Y, Pan Y, He S, Dai Y, Zhu B, Wei C, Xin L, $\mathrm{Xu} \mathrm{W}$, Xiang $\mathrm{C}$, Zhang S. Endometrial stem cell-derived granulocyte-colony stimulating factor attenuates endometrial fibrosis via sonic hedgehog transcriptional activator Gli2. Biol Reprod. 2018;98:480-90.

33. Peng J, Li M, Zeng H, Zeng Z, Huang J, Liang X. Intrauterine infusion of platelet-rich plasma is a treatment method for patients with intrauterine adhesions after hysteroscopy. Int $\mathbf{J}$ Gynaecol Obstet. 2020;151:362-5.

34. Zhang Z, Li S, Deng J, Yang S, Xiang Z, Guo H, Xi H, Sang M, Zhang W. Aspirin inhibits endometrial fibrosis by suppressing the TGF- $\beta 1$-Smad2/Smad3 pathway in intrauterine adhesions. Int $\mathrm{J}$ Mol Med. 2020;45:1351-60.

35. Amer MI, Abd-El-Maeboud KH. Amnion graft following hysteroscopic lysis of intrauterine adhesions. J Obstet Gynaecol Res. 2006;32:559-66.

36. Chen Y, Liu L, Luo Y, Chen M, Huan Y and Fang R. Effects of Aspirin and Intrauterine Balloon on Endometrial Repair and Reproductive Prognosis in Patients with Severe Intrauterine Adhesion: A Prospective Cohort Study. Biomed Res Int. 2017;2017:8526104.

37. Zhang W, Tang N, Li X, George DM, He G, Huang T. The top 100 most cited articles on total hip arthroplasty: a bibliometric analysis. J Orthop Surg Res. 2019;14:412.

38. Borgatti SP, Mehra A, Brass DJ, Labianca G. Network analysis in the social sciences. Science. 2009;323:892-5.
39. Ahmad SS, Ahmad SS, Kohl S, Ahmad S, Ahmed AR. The hundred most cited articles in bariatric surgery. Obes Surg. 2015;25:900-9.

40. Schenker JG. Etiology of and therapeutic approach to synechia uteri. Eur J Obstet Gynecol Reprod Biol. 1996;65:109-13.

41. Khan Z, Goldberg JM. Hysteroscopic management of Asherman's syndrome. J Minim Invasive Gynecol. 2018;25:218-28.

42. Cervelló I, Gil-Sanchis C, Santamaría X, Cabanillas S, Díaz A, Faus A, Pellicer A and Simón C. Human CD133(+) bone marrowderived stem cells promote endometrial proliferation in a murine model of Asherman syndrome. Fertil Steril. 2015;104;1552-60. e1-3.

43. Sedgh G, Bearak J, Singh S, Bankole A, Popinchalk A, Ganatra B, Rossier C, Gerdts C, Tunçalp Ö, Johnson BR Jr, Johnston HB, Alkema L. Abortion incidence between 1990 and 2014: global, regional, and subregional levels and trends. Lancet. 2016;388:258-67.

44. Cameron S. Recent advances in improving the effectiveness and reducing the complications of abortion. F1000Res. 2018;7.

45. Guo C, Pang L, Wen X, Zheng X. Risky sexual behaviors and repeat induced abortion among unmarried young women in China: results from a large, nationwide, population-based sample. J Womens Health (Larchmt). 2019;28:1442-9.

46. Zong Z, Sun X, Mao J, Shu X, Hearst N. Contraception and abortion among migrant women in Changzhou, China. Eur J Contracept Reprod Health Care. 2020. https://doi.org/10.1080/13625187. 2020.18209791-6.

47. Jiang Y, Han J, Donovan C, Ali G, Xu T, Zheng Y, Sun W. Induced abortion among Chinese women with living child-a national study. Adv Dis Control Prev. 2017;2:10-5.

48. Zeng Y, Hesketh T. The effects of China's universal two-child policy. Lancet. 2016;388:1930-8.

49. Cao Y, Sun H, Zhu H, Zhu X, Tang X, Yan G, Wang J, Bai D, Wang J, Wang L, Zhou Q, Wang H, Dai C, Ding L, Xu B, Zhou Y, Hao J, Dai J and Hu Y. Allogeneic cell therapy using umbilical cord MSCs on collagen scaffolds for patients with recurrent uterine adhesion: a phase I clinical trial. Stem Cell Res Ther. 2018;9.

50. Lin N, Li Xa, Song T, Wang J, Meng K, Yang J, Hou X, Dai J and $\mathrm{Hu} \mathrm{Y}$. The effect of collagen-binding vascular endothelial growth factor on the remodeling of scarred rat uterus following full-thickness injury. Biomaterials. 2012;33(6);1801-7.

51. March CM, Israel R. Intrauterine adhesions secondary to elective abortion. Hysteroscopic diagnosis and management. Obstet Gynecol. 1976;48:422-4.

52. March CM, Israel R. Gestational outcome following hysteroscopic lysis of adhesions. Fertil Steril. 1981;36:455-9.

53. March CM, Israel R, March AD. Hysteroscopic management of intrauterine adhesions. Am J Obstet Gynecol. 1978;130:653-7.

54. Yang J-H, Chen M-J, Wu M-Y, Chao K-H, Ho H-N, Yang Y-S. Office hysteroscopic early lysis of intrauterine adhesion after transcervical resection of multiple apposing submucous myomas. Fertil Steril. 2008;89:1254-9.

55. Yang J-H, Chen M-J, Chen C-D, Chen S-U, Ho H-N and Yang Y-S. Optimal waiting period for subsequent fertility treatment after various hysteroscopic surgeries. Fertil Steril. 2013;99(7):2092-6. e3.

56. Takai IU, Kwayabura AS, Ugwa EA, Idrissa A, Obed JY, Bukar M. A 10-year review of the clinical presentation and treatment outcome of Asherman's syndrome at a center with limited resources. Ann Med Health Sci Res. 2015;5:442-6. 
57. Kou L, Jiang X, Xiao S, Zhao YZ, Yao Q, Chen R. Therapeutic options and drug delivery strategies for the prevention of intrauterine adhesions. J Control Release. 2020;318:25-37.

58. Berman JM. Intrauterine adhesions. Semin Reprod Med. 2008;26:349-55.

59. Santamaria X, Mas A, Cervello I, Taylor H, Simon C. Uterine stem cells: from basic research to advanced cell therapies. Hum Reprod Update. 2018;24:673-93.

60. Cao Y, Sun H, Zhu H, Zhu X, Tang X, Yan G, Wang J, Bai D, Wang J, Wang L, Zhou Q, Wang H, Dai C, Ding L, Xu B, Zhou Y, Hao J, Dai J, Hu Y. Allogeneic cell therapy using umbilical cord MSCs on collagen scaffolds for patients with recurrent uterine adhesion: a phase I clinical trial. Stem Cell Res Ther. 2018;9:192.

61. Chen L, Qu J and Xiang C. The multi-functional roles of menstrual blood-derived stem cells in regenerative medicine. Stem Cell Res Ther. 2019;10;
62. Ma H, Liu M, Li Y, Wang W, Yang K, Lu L, He M, Deng T, Li $\mathrm{M}, \mathrm{Wu} \mathrm{D}$. Intrauterine transplantation of autologous menstrual blood stem cells increases endometrial thickness and pregnancy potential in patients with refractory intrauterine adhesion. J Obstet Gynaecol Res. 2020;46:2347-55.

63. Azizi R, Aghebati-Maleki L, Nouri M, Marofi F, Negargar S, Yousefi M. Stem cell therapy in Asherman syndrome and thin endometrium: stem cell- based therapy. Biomed Pharmacother. 2018;102:333-43.

64. Santamaria X, Liu JH, Aghajanova L, Isaacson K, Movilla P, Fernandez H, Capmas P, Donnez J, Simón C. Should we consider alternative therapies to operative hysteroscopy for the treatment of Asherman syndrome? Fertil Steril. 2020;113:511-21.

65. Koythong T, Guan X. Consideration for an optimal and practical approach to hysteroscopic adhesiolysis of intrauterine adhesions. Ann Transl Med. 2020;8:663. 